Marquette University

\title{
e-Publications@Marquette
}

Management Faculty Research and

Publications

Management, Department of

Spring 1995

\section{Belated Recognition for Work Flow Entrepreneurs: A Case of Selective Perception and Amnesia in Management Thought}

Leonard R. Sayles

Columbia University

Alex Stewart

Marquette University, alex.stewart@marquette.edu

Follow this and additional works at: https://epublications.marquette.edu/mgmt_fac

Part of the Business Commons

\section{Recommended Citation}

Sayles, Leonard R. and Stewart, Alex, "Belated Recognition for Work Flow Entrepreneurs: A Case of Selective Perception and Amnesia in Management Thought" (1995). Management Faculty Research and Publications. 202.

https://epublications.marquette.edu/mgmt_fac/202 
Marquette University

e-Publications@Marquette

\section{Management Faculty Research and Publications/College of Business Administration}

This paper is NOT THE PUBLISHED VERSION; but the author's final, peer-reviewed manuscript. The published version may be accessed by following the link in the citation below.

Entrepreneurship Theory and Practice, Vol. 19, No. 3 (April 1, 1995): 7-23. DOI. This article is (C SAGE Publications and permission has been granted for this version to appear in e-Publications@Marquette. SAGE Publications does not grant permission for this article to be further copied/distributed or hosted elsewhere without the express permission from SAGE Publications.

\section{Belated Recognition for Work Flow Entrepreneurs: a Case of Selective Perception and Amnesia in Management Thought}

Leonard R. Sayles

Emeritus at Columbia University

Alex Stewart

Texas Tech University

\section{Abstract}

Recent trends, such as reengineering, require work flow entrepreneurship. Important principles about these practices were recognized in post-World War II field research, but by the 1970s this work suffered neglect. Amnesia was caused by deeply held assumptions of scientific management, and by a search within business schools for academic legitimacy at the expense of praxis, which skewed the perspectives with which organizations were viewed. 
Managers at a U.S. manufacturer learn, through trial and error, how to improve horizontal work flows. They find they must ensure that someone is clearly responsible for all important processes. Productivity significantly improves; the hierarchy flattens. Despite these results, management pushes hard for further, continuous improvements.

Reengineering activities such as these receive celebration in the current business press (e.g., Byrne, 1993). In this article, we make two sets of claims about these efforts. We hold that these efforts are a type of working leadership (Sayles, 1993), that this working leadership is work flow entrepreneurship, and that work-flow entrepreneurship is an important dimension of firm-level entrepreneurship. Next, we demonstrate that within the anthropological fieldwork tradition these ideas are rather old. For example, the site in our opening vignette is Plant No. 1 of the IBM Corporation; the date is half a century ago (Richardson \& Walker, 1949).

If reengineering is important, why would the earlier ideas have been forgotten? We argue that amnesia in management thought resulted both from the psychologizing of issues that properly require attention to work flow process and technology. "Attention" is too weak a word; understanding work flow process requires research of a kind that became increasingly rare: up-close, in the field, in close collaboration with people on the floor. This is a lens, a methodological and disciplinary perspective that is needed to understand organizations. In Part II, we suggest that the lens a researcher uses affects not only the perspective on the same "real" object under study, it provides access to distinct realities. To demonstrate this point, we view the social network of the same entrepreneurial organization from a psychological, a cognitive, a political, and a work/economic perspective. These four views prove to be meaningfully and structurally distinct.

\section{WORKING LEADERSHIP AS FIRM-LEVEL ENTREPRENEURSHIP}

Work flow working leadership is a form of firm-level entrepreneurship; this is our central thesis. What, then, do we mean by "entrepreneurship" at the level of the firm? Our definition of "entrepreneurship" in this context has three components. First, it is activity that seizes profit opportunities without regard to resources currently controlled (Stevenson \& Jarillo, 1990). Second, it expands existing resource bundles through enhanced learning, synergies, or factor input completion (e.g., bootstrapping) (Burgelman, 1983; Leibenstein, 1968; Stewart, 1989; Venkataraman, MacMillan, \& McGrath, 1992). These resource expansions result in rent.(1) Third, it promotes change and innovation leading to new combinations of resources, including new process technologies and new work systems (Burgelman, 1983; Schumpeter, 1943, p. 132). The managerial activity that creates new combinations typically takes place in organizational contexts characterized by teamwork, empowered operating level employees, organic structures, and fluid, informal networking (Covin \& Slevin, 1991; Zahra, 1993).

\section{New Resource Combinations and Organizational Entropy}

On the face of it, all three components of our definition, as well as the attendant managerial activities, are fairly well developed in the literature. We believe, however, that the nature of input completion in the work system is not well understood. The work system has a ceaseless need for enhancements, due to the fundamental,

profound problem of coordination. Again, on the face of it, the concept of coordination is unproblematic. Often, however, it is barely understood, and more often it is misconstrued, because it tends to be seen as the concern of planning, organizational structure, and hierarchical politics. These lenses are those of Generally Approved Management Principles, or GAMP (Sayles, 1993, pp. 25-26). GAMP, the widely accepted scientific management, command, motivate and control model, fails to recognize the persistent need for everyday initiatives by middle managers for "continuous mutual adaptation and retrofitting" of work flows (Sayles, 1993, p. 36). The planning and control mentality fails to acknowledge that "without substantial managerial inputs of interest and energy and initiative, work inevitably degrades" (Sayles, 1993, p. 19). 
GAMP fails to catch this because it does not account for their realities of work flows. Managers, and field researchers, find that vertical and horizontal interfaces between tasks and job responsibilities are never neat. In practice, managers' roles are ambiguous and overlapping. Managerial roles entail extensive and complex interdependencies, but discrepant goals, incentives, and orientations. The interconnections among teams and supervisory units are difficult to stabilize. Changes in one task ripple throughout a system of tasks. Two sources of instability are particularly noteworthy. First, there is the problem of suboptimization. There are countless discretionary performance choices in which optimality for the small group is system degrading. The subtle complexity of interfaces that results is not accounted for in supervisory or engineering task specifications. Second, these are constantly in flux as managers seek to be responsive to changing product mix, customization requests, technology modifications, and pressures to meet new performance targets (cf. Hammer \& Champy, 1993, p. 17). In most large organizations, these stresses are exacerbated by excessive complexity and buildup of staff (Sayles, 1962b, p. 85; 1993, pp. 10-11, 42; cf. Hammer \& Champy, 1993).

\section{Working Leaders}

Ambiguous interfaces and other sources of entropy are held, within GAMP, to be abnormal, exceptions to programmable work. But these sources of entropy are, we hold, the norm (Sayles, 1962b). They remain unresolved by plans or programmed work. They can be resolved only by creative interventions by people who we call "work flow" entrepreneurs - middle managers who fine-tune coordination and create core operating competencies. These are people like Max of "MIDA" (Stewart, 1989, chap. 3) and Kay Cohen of "Process Chemicals" (Sayles, 1993, chap. 9). Without their initiative in getting resources redistributed, job and group boundaries changed, and upper management rules and policies modified, their organizations would not have achieved the high levels of effectiveness they were seeking.

People such as these are, in the title words of Sayles (1993), "working leaders." Working leaders are operatinglevel managers who take initiatives based on their "capacity to make fast-paced tradeoffs (each involving embedded people and technology issues) focusing on the ever-changing needs of coordination and the overall system" (Sayles, 1993, p. 13).

The Kay Cohen case (Sayles, 1993, pp. 158-168) illustrates the ways in which working leaders create lateral and horizontal linkages to use resources that they do not directly control (cf. Stevenson \& Jarillo, 1990). This case shows how integrating the semi-autonomous work flow stages requires adept, entrepreneurial managers who can bend rules, get constraining staff groups to change specifications, and arrange compromises and consensus among dispersed interdependent supervisory units (many of whom will report to different functional or regional managers). Their integration role requires continuous negotiation, moving from one source of stalemate or inefficient interconnection to another, along the work flow chain and among the many staff and technical groups that typically have "hands in" the system parameters. A great deal of creative improvisation is required: an entrepreneurial, not a bureaucratic view of the managerial role.(2)

Entrepreneurial networking within the firm is needed because, as one of us argued some years ago, "organizations are changing into structures where lateral relations predominate, where there are tremendous numbers of overlapping networks of servicing, staff, and specialized interest groups. In order to get your job done, you, as the manager, must influence large numbers of people, over most of whom you have zero authority" (Sayles, 1962b, p. 85). Around the same time, William Foote Whyte (1969, pp. 636-637; see also Sayles, 1962a, pp. 66-67; 1962b, p. 85) recognized the role of informal networking in the work of "engineers as internal entrepreneurs":

How can engineers cope with . . . changing group membership and changing task assignments? [They] develop what we might call an entrepreneurial role... . The leader of an engineering project group ... does not wait passively to see what management has to assign him [or] his current associates. If he feels that he [has] an 
effective working team, he will make every effort to keep that team together.... He keeps in touch with influential individuals [and outside] activities ... and [potential] profitable lines of investment. ... He then conspires with his work group to do a little ... "bootlegging" (Whyte, 1969, p. 636).

\section{FINDING, FORGETTING, AND REINVENTING WORK FLOW ENTREPRENEURSHIP}

Work flow initiatives by working leaders create new systems of work flows, and hence new resource combinations (Sayles, 1962a, pp. 62, 65; Stewart, 1989, chap. 3). These new combinations create competitive advantage through work systems that work better than those of other firms (cf. Hammer \& Champy, 1993, p. 26). At this time, there is very substantial interest in this approach to competition, expressed in approaches such as reengineering (Hammer \& Champy, 1993), the horizontal corporation (Byrne, 1993), world-class manufacturing (Schonberger, 1986), or lean production (Womack, Jones, \& Roos, 1990).(3) Enumerating all of these approaches from this point on would be too unwieldy; we will focus on reengineering, with references to other practices in the strategic management of operations.

\section{The Importance of Operations and of Work Flows}

Anthropologically oriented studies did not foresee all the ideas to be found in reengineering, but they captured most of the core ideas. A foundational concept shared by both is that operations are important. This concept is implicit in the view of "work flow as the basis for organization design" (Chapple \& Sayles, 1961, chap. 2), as well as in the detailed attention to specific operations systems, such as in Richardson (1961). Field studies and reengineering also share the view that, within operations, work flows are critically important. This was a theme of much anthropologically oriented research (Arensberg \& Tootell, 1957; Morey \& Luthans, 1987).

Field studies highlighted the degree of uncertainty in what the researchers called lateral or horizontal relations (in contrast to vertical or hierarchical relations). Because jobs did not automatically fit or complement each other, there was the need for much more lateral interaction than management theory had envisioned. Traditional leadership and organization theory always distinguished between the managerial challenge of nonroutine work like R\&D, where there might well be substantial "lateral" interaction, and what was presumed to be the clearly prescribed work of most production operations, the machine bureaucracies. For example, in Perrow's influential Complex Organizations: A Critical Essay (1979), work-oriented interaction was almost always "vertical"; the "horizontal" were fun and games or protest actions. The literature on corporate entrepreneurship has also tended to focus more on the vertical, bottom-up championing process than on the horizontal activities of working leaders (with some exception in Burgelman \& Sayles, 1986, pp. 75-79, 158-159; cf. Venkataraman et al., 1992, pp. 502-507).

The importance of coordinating lateral ties that was apparent in much field research ran counter to prevailing scientific management ideas, which focused instead on specialization and task design. A well-known study that demonstrated the field-research finding was by the British Tavistock Clinic,(4) in an Indian setting:

An Indian textile mill seeking to modernize and attain the advantages of specialization and scientifically engineered work standards "re-engineered" the work. Twelve tasks were prescribed for the mill. The mill was subdivided into units of $\mathbf{2 4 0}$ looms. For each such unit, work was subdivided such: The highest skilled worker, a weaver, would tend 30 looms; the next highest skilled, a "battery filler" served 50 looms. And the third most skilled, the "smash hand" had 80 looms to service. The other nine job classifications had from 120-240 looms to work on, depending on the difficulty of their particular task.

As one could predict, the mill failed to attain its predicted productivity. The Tavistock researchers found, not surprisingly, that there were countless coordination problems. These had been unpredicted by the engineers 
who conceived these 12 differentiated tasks as autonomous. Instead there was the need for almost continuous interaction among employees in order to facilitate the right sequence of task performance since many of the breakdowns and servicing requirements were random.

Resupplying, repairing and resetting the looms thus required teamwork and mutual cooperation. It was obviously a naive assumption of the engineering work standards that a weaver, for example, would have fiveeighths of a "battery filler" for his or her looms (summarized from Rice, 1955).

\section{A Process View of Work}

The Tavistock lessons were also discovered in practice by managers. About this same period IBM began experimenting in one of its upstate New York plants - the plant of our opening vignette - with reducing specialization by enlarging jobs, and found the results impressive in improving coordination (Richardson \& Zimmerman, 1965). One reason for their success, apparently, was the prescient development of lean or worldclass manufacturing practices such as simplified work flows. Another was the limitations of the scientific management and bureaucratic practices that were replaced.

Our reading of the earlier studies suggests that individual field-research-based case studies over almost half a century were disclosing that many presumed machine-like technologies actually contained many inherent sources of breakdown and imperfection. Fifty years later, both researchers and practitioners were still relearning these simple findings. All the efforts to simplify jobs and optimize work the task level have been an abysmal failure. Reengineering, for example, replaces complex processes and simple jobs with simple processes and complex jobs (Hammer \& Champy, 1993, p. 51).

The price to be paid in coordination problems, for bureaucratic complexity, was revealed by the wide range of organizational pathologies that field researchers uncovered. Many of these findings were summarized in Whyte's book, Organizational Behavior (1969, pp. 372, 399-415, 619-639; see also Richardson \& Walker, 1949; cf. Hammer \& Champy, 1993, p. 4). Field studies were disclosing that there could be substantial coordination problems within management itself. Particularly, the rapid multiplication of staff and support groups led to struggles over who should do what and who should defer to whom, struggles that sapped management time and effectiveness.

In the 1940s students of industrial relations began to recognize another cost of complexity. Unions could exploit management's infatuation with specialization. So-called "working to rule" would devastate overall performance even when all employees were correctly doing their jobs. Craft jobs that had been subdivided in order to provide lower training and wage costs could be difficult to coordinate. The result could be higher employment levels and total labor costs than would have resulted from allowing employees to do more well-rounded, more highly skilled jobs (Slichter, 1941).

Costs of coordination due to excessive complexity and susceptibility to working-to-rule are two reasons that scientific management did not work. Another reason was its failure to manage the boundaries between management jurisdictions or the barriers of time and space. Sayles (unpublished files) observed a large service organization in the 1950s that had increased the amount of specialization in carpenter jobs in maintenance. In one absurd example, the replacement or addition of a door required that specialists in door jambs, door locks, door closers, and door "bodies" coordinate their work in time and space. The reality was a great deal of waiting time. It was rare that the jamb and closer specialists, for example, would be free and converge at the fight place and the right time. Clearly, coordination problems were not unique to R\&D or to high-tech environments.

The conclusion was that management needed to undertake a kind of work floor "social engineering" to avoid logical specialization becoming destructive of efficiency (Trist, Higgin, \& Murray, 1963; Chapple \& Sayles, 1961). The solution was for first line managers to build teams whose critical problems of interdependence could be 
solved by continuous exchange (of information, assistance, or even job modification). Proximity, common goals, and common supervision facilitate the creation of self-maintaining small systems. "A single supervisor" (Chapple \& Sayles, 1961, p. 25) takes responsibility for "a single flow." His or her responsibilities are determined by an understanding of "processes" in the work flows. Whatever the apparent, functional character of work, Chapple and Sayles (1961, p. 21) argued, the fundamental unit of organization is a "process" (p. 34). For in all work flows, "there is a beginning, when the process starts, something is done, and the process ends. ... Something comes in the door, something is done to it, and it moves on its way out another door to the customer."

\section{Why Were the Lessons Not Learned?}

These are lessons of reengineering, lessons that were, unfortunately, not well learned. "Organizations keep discovering the advantages of having interdependent functions encapsulated within an organizational unit. ... This obvious advantage of organizing on the basis of interdependence rather than functional specialty could only be missed by a GAMP-trained manager who still believed that all communications must flow through the common boss" (Sayles, 1993, p. 170; cf. Burns \& Stalker, 1966, pp. 92-93; Chapple \& Sayles, 1961, pp. 19-21; Richardson, 1961, pp. 68-69).

Why have these lessons had to be rediscovered?(5) One reason is that they never met with wide acceptance (Arensberg \& Tootell, 1957, p. 334). They stood in direct contrast to GAMP and scientific management. Our worldviews affect how we process information. For example, the Tavistock studies, such as Rice's (1955), noted above, were widely cited and disseminated in schools of business. These studies clearly challenged all the traditional assumptions about neatly prescribed autonomous jobs. But they had little impact on conceptions of managerial work and what was organizationally problematic (cf. Trist et al., 1963). For more than twenty years the findings of studies like these were distorted by the well-accepted paradigms of management and industrial psychology. These took as given that (1) the jobs of both workers and managers can be specified clearly and unambiguously such that they do not overlap, and (2) increasing specialization by subdividing existing tasks or adding more specialists has no consequential organizational cost.

To facilitate high levels of teamwork, which were unspecified in traditional job descriptions but called for in practice, perspicacious and energetic managers were needed. But they were not being produced by U.S. management development processes. The latter presumed that the deft handling of power and authority (vis-avis subordinates and superiors) was what was most problematic. Management thought was biased towards vertical, formal authority, and against lateral, informal influence. Hence, findings in field research about intramanagement conflict (for example, staff-line conflicts, as in Dalton, 1959) were interpreted in traditional terms. Rather than viewing these, at least in some measure, as coordination issues, academic writers interpreted the rich case data in terms of familiar hierarchical power struggles and organizational "politics" (cf. Pettigrew, 1973, Pfeffer, 1992).

Within the management academy, a powerful influence affecting the interpretation of field research findings was the discipline of psychology. In the 1960s, U.S. business schools strove to overcome their academically stigmatized pasts, becoming more Mandarin than the Mandarins (Porter \& McGibbin, 1988; Stewart, 1995). Viewed through the lens of psychology, the field research was not seen as challenging existing paradigms of scientific management concerning highly autonomous, well-bounded jobs. Rather, the studies were "reinterpreted" to be consistent with existing theories of psychic deprivation inherent in industrial jobs (Hackman \& Suttle, 1977; cf. Guest, 1962; note that Richardson [1961] himself adopted a social psychiatric perspective influential at the time).

The field study data discussed above was then "transmuted" into a motivational context. More specialized jobs injured motivation because they provided less job satisfaction (Herzberg, Mausner, \& Snyderman, 1959). Employees working within groups gained more social satisfaction from group membership. And work teams 
could improve performance insofar as they reduced the need for managerial order-giving. This reduced the sting of authority. There was little or no recognition, in this revisionist reading, of the crucial role that teams could play in coping with the inherent ambiguities in work or the likelihood that jobs would overlap and therefore require a great deal of mutual give and take if a high level of quality and efficiency was to be attained.

To be sure, there are job satisfaction issues embedded in the studies cited, but the primary "discovery" of the anthropological-style field work of those decades was lost. That "discovery" was that the appearance of precisely interlocked jobs was more myth than reality. Just as important, if not more important, than the "inside" of a task was the "outside" - that is, the interface between and among tasks. Getting work done in such a way that the task performance of individuals is mutually complementary and not contradictory is one of the major challenges of management. This "dark side" of specialization was what got lost in the motivational reinterpretation of those field studies.

Management professors (like many line managers) are ill at ease dealing with technology; they are more comfortable with problems of individuals and hierarchy. The problems at managerial levels are taken to be external: finding the right strategy and competitive behavior. Management professors (like some managers) are more at ease with grand strategizing, or strategy "content." In practice, strategy content centers on extremely broad-brush decisions about which professors can, purportedly, offer prescriptive advice (cf. Wernerfelt, 1995, for a more modest perspective).

\section{Learning from Experience}

Field researchers are unlikely to offer grand strategic advice. However, they can claim that their grounded case studies may challenge existing paradigms. Quantitative techniques, particularly survey research, typically are employed deductively, testing hypotheses derived from accepted models of reality. This style of research can be justified on the grounds that it can discover potentially useful principles that have not been discovered in, and cannot be disclosed by observation of, practice. However, deductive researchers typically fail to challenge the dominant paradigms of practice, such as GAMP, because they do not start with the premise that we do not know what is managerially problematic. The result is that deductive research, far from challenging the dominant paradigm, reinforces it.

In contrast, field research is essentially an inductive method. The researcher seeks to comprehend "reality" by carefully observing and interviewing, and then inductively seeking regularities. Field research, at its best, does not take for granted what is problematic, what are the critical variables to which the manager should attend (for goal attainment), and what are consequential interrelationships in organizational behavior. The armchair academic simply knows that the middle manager's everyday work, in large firms, cannot be entrepreneurial.(6) We have looked and found otherwise.

Ironically, field researchers learned about the limits of GAMP by direct interaction with managers, but managers did not, in the aggregate, learn from them. And little in the U.S. managers' environment would induce them to alter their bureaucratic mindset. For so many years after World War II American managers found it easy to believe that the stultifying principles of scientific management were still applicable. Many larger companies were oligopolies; profits came relatively easily. It appeared as though only financial/strategic decision making mattered. Getting the "real work done," the work of operations, was straightforward, rationalistic industrial engineering. Industrial psychologists reassured them that the only real problems were motivational, relating to job satisfaction (and supervisory insensitivity). Thus, it is not surprising that American management did not view operating excellence as a particular challenge. New paradigms surrounding systems and operations only got accepted by academics and managers when competitive pressures became severe. 
The relatively recent emphasis in the corporate world and academia on operating effectiveness as a management strategy challenges the comfortable presumption that "new" research data from case and field studies serve to modify or change well-accepted management belief systems (paradigms). Almost fifty years ago data began emerging challenging the scientific management emphasis on specialization and suggesting that coordination was much more problematic than most managers presumed. However, until a significant share of consumer electronics manufacturing shifted to Asia (although American invention had been preeminent) and the American auto industry suffered very painful losses in income and market share, little attention was paid to execution in American industry or American business schools.

Our account raises questions about the efficiency with which new knowledge is created and disseminated in the management and organization studies fields. The research stream we report on did not have an apparent impact on management thinking until the 1990s, and even then its insights went unacknowledged. Possibly we ought not to be surprised by this. This is scarcely the first time that management writings have failed to be used by practitioners (Porter \& McGibbin, 1988; Stewart, 1995). But this attitude seems to us too defeatist. Therefore, we raise the question, how can we avoid such amnesia in the future?

\section{Part II}

Understanding organizations requires more than attention to cognition and to affect, studied at a distance; it requires attention to work flow patterns and to informal politics, studied up-close. We demonstrate this point with a social network analysis of an entrepreneurial firm.

\section{AVOIDING AMNESIA IN MANAGEMENT THOUGHT}

We have argued that academic amnesia is caused by selective perception, which in turn is caused by particular disciplinary approaches. Morgan (1986) has argued that we ought to use multiple approaches, or "metaphors," because all of them reflect organization. An organization is simultaneously a "machine," a "political system," a "culture," and so on. We agree. But a question remains: is the organization, qua polity, materially distinct as a "real" entity, from the organization qua culture, qua work system, qua personality system? In social network terms, this question can be expressed in terms of multiplexity.

\section{Multiplex Networks, Multiple Metaphors}

Social networks have multiple, distinct relational or transactional contents. For example, actors may have ties of friendship, political activism, kinship, and economic exchange. Following Wasserman and Faust (1994), we will refer to these and other content domains as "relations." Although we assume that most actors within an organization are involved in multiple relations, and thus have multiplex ties with one another, the term "multiplexity" technically refers to redundancy among these relations (Johnson \& Miller, 1986), such that no further information about network structure is obtained by knowing about more than one type of tie. Thus, if we wish to find out if it matters whether or not we view organizations through only one disciplinary lens, we ask if the social networks of the organization are multiplex. If they are, disciplinary perspectives make no difference. The same object is merely viewed from a different angle. If, however, the structure of networks differs materially between the relations, disciplines matter. The objects that are viewed are not the same.

\section{Method: Integrating Ethnographic Data with Network Analysis}

Many, perhaps most, network studies have not attempted to distinguish relations, and most efforts to do so have been seriously limited (Burt, 1983). There is, however, some evidence that small organizations are not multiplex (i.e., that their relations are not merely redundant). Johnson and Miller (1986, p. 75) concluded that "kinship data, economic exchange data, or co-residence data alone would have led us to a biased interpretation of the social structure of the fishermen" studied. Brajkovich (1994) studied an entrepreneurial organization; 
unlike Johnson and Miller, he did not obtain most of his data from observations. He found relatively little multiplexity, but did find it between what he called work networks and work activities.

What remains to be done, to answer our question, is to measure organizational activity from the perspectives of major disciplinary traditions. The substantive focus of each tradition can be construed as a relation, in the sense in which we use this term. In order to measure relations, we(7) used the data on an entrepreneurial company, called MIDA. These data, upon which Stewart had based his 1989 ethnography, were indexed using the Ethnograph software package (Seidel, Kjolseth, \& Seymour, 1988; Stewart, 1994 discusses how this was done; Stewart \& Krackhardt, 1995 provides a detailed explanation of our method). This enabled us to count each instance in which any actor was the sender of a tie with respect to any index word, to any other actors in the firm. The index words were categorized as distinctively referring to either (1) the "heart" (the affective or personality system), (2) the "head" (cognition), (3) the "polity" (power and influence) or (4) the "machine" (the work and economic-related system). For example, the index words used for the cognitive relation are DEBATE, DECIDE, DIFF(erent) VIEW, DISAGREE, FEEDBACK, PROB(lem) SOLVE, SOLVE, SUGGEST, and TRAIN.(8)

\section{Comparing Disciplinary Lenses by Comparing Relational Structures}

How different are the network structures of the four different relations? Does the Affective/Personality relation, which psychologically oriented scholars might study, differ much from, say, the Work relation, which is the basis of work flows and reengineering? This question can be posed as one of network roles, or patterns of similarities in ties among actors. Across the four relations, are actors similar, in their pattern of ties, to the same other actors? We treated this question as one of structural equivalence, which means we focused on the extent to which actors "have identical ties to and from all other actors in the network" (Wasserman \& Faust, 1994, p. 356), across the four relations. One of the earliest and most widely used analytical techniques for determining structural equivalence is CONCOR (CONvergence of iterated CORrelations) (Breiger, Boorman, \& Arabie, 1975).(9) CONCOR is an iterative procedure in that the outcome of one correlation becomes input to the next, and a convergent procedure because it ultimately partitions actors until they are positively correlated with those within the same position, and negatively correlated with those in other positions.

Figure 1 presents the CONCOR partitions (from UCINET IV, Borgatti, Everett, \& Freeman, 1992) for the four relations. In the dendograms, "those actors who are connected by [unbroken strings of Xs higher] in the diagram are closer to being perfectly structurally equivalent, whereas subsets of actors who are joined only [lower down] in the diagram are less structurally equivalent (or not equivalent at all)" (Wasserman \& Faust, 1994, p. 378). Inspecting these dendograms for differences is time consuming. One way to summarize the differences is to say that, if an actor is maximally (i.e., level 5) equivalent to another actor, there is little tendency to be closely equivalent to that actor in the other three relations. The 23 actors are, in at least one relation, maximally equivalent to 94 other actors, an average of 4.1 per actor. For these same dyads, there are only 26 cases in which they are maximally equivalent in one of the three other relations, an average of 1.0 per actor. There are 96 cases in which they are maximally distinct (level 1 ) in another relation, for an average of 4.2 per actor.

Perhaps the clearest way to express the distinctions among the relations is with correlations of structural equivalences. Correlations of the first CONCOR iteration are presented in Table 1. The four relations are more highly correlated than one would anticipate by chance. After all, they all reflect "takes" on a unitary stream of social action, within the same, relatively small set of actors. However, in only one of the six comparisons is the correlation above $50 \%$. In most comparisons, there is less in common than not in common between relations. The lenses have not just seen different angles, but to a considerable extent different organizations.

In making this claim, we distinguish statistical from substantive significance. We will demonstrate this distinction by examining two of the most similar relations, those of Work/Economic Activity and Affect/Personality. These relations are not statistically significantly different, with a correlation coefficient of 0.47 . However, important 
sets of ties differ between them. (Note that we here refer to direct ties, not to similarities in patterns of ties, as reflected in the CONCOR analysis.) In the former relation, there is one particularly strong tie, between Peter and William, with a moderately strong tie between Fred and Wally. In the latter, there is one particularly strong tie, between Peter and Hector, with moderately strong ties between Peter and Max, Peter and William, and Peter and Carol, and ties that are nearly as strong between Hector and Howard, Peter and Howard, Ralph and Max, and Fred and Zhong-shi. We also find many differences if we inspect the degree (number of ties) of each actor. For example, Hector is connected to nine actors, generally weakly, in the Work relation. He is connected to six, one very strongly, in the Affective relation. This is true in general of several other actors; Yong-sheng has six connections in Work and one in Affect. The four relations are more correlated than expected by chance, but it is very hard to consider them the same.

\section{IMPLICATIONS}

Methodologically, all four of these relations were constructed from ethnographic field data. In our view it would be impossible to capture these relations, or other more subtle and private relations such as negativity, by any other means. Even if actors were willing to give frank answers to an outside researcher about all of their ties, they would be cognitively incapable of making the distinctions (Brajkovich, 1994; Burt, 1983; Johnson \& Miller, 1986; Stewart \& Krackhardt, 1995). If, as we have argued, the relations are meaningfully different, and if, as we have admittedly assumed, the relations all have importance, there is only one methodological conclusion. Upclose field research is needed. Research of this kind led to the work flow insights of the postwar generation of American industrial ethnography. Its misperception by armchair academics engendered amnesia.

Currently we witness a new generation of field researchers in management, as demonstrated by this issue. Naturally, we find this development encouraging. But we do have two concerns. First, there is little in-depth ethnography in this issue, or in entrepreneurial studies (Aldrich, 1992; John Van Maanen, personal communication, 1995). The reason may be that ethnography takes too long for the publish-or-perish Mandarinism of business schools (Stewart, 1995). This may account for the popularity of rapid appraisal approaches, reflected in this issue, such as grounded theory based on interviews, and network analysis based on questionnaire data.

Our second concern is that, even if this generation does learn much that is worth knowing, their work, like that of their academic predecessors, may be misperceived and forgotten as well. In the final article in this issue, there are suggestions for ways to avoid this fate by cumulating field-research-based knowledge. We close this article with two other research suggestions.

First, if we as researchers venture to muddy our boots in the field, we should keep our eyes and ears wide open. "In the observations and interviews" of the Hawthorne researchers, "shorthand sociological and psychiatric concepts are repeatedly substituted for actual first-order abstractions: the who does what to whom, when, and where, of the anthropological field method" (Chapple \& Sayles, 1961, p. 198). Clearly, the latter, not the former, is what we counsel. We will not learn about the subtleties of work flows, informal political networks, or sundry other matters, with stringent sensory lenses. That appears to be a lesson of our network demonstration.

Table 1 Correlation Matrix of Structural Equivalence, from First CONCOR Iteration, for Four Relations, from MIDA, 1984

\begin{tabular}{|l|l|l|l|}
\hline & Affective & Cognitive & Work \\
\hline Cognitive & $0.21\left(^{* *}\right)$ & & \\
\hline Work & $0.47\left(^{* *}\right)$ & $0.18\left(^{* * *}\right)$ & \\
\hline Political & $0.34\left(^{* * *}\right)$ & $0.53(* * *)$ & $0.25\left(^{* * *}\right)$ \\
\hline
\end{tabular}

** = Significant at the 95\% level. 
$* * *=$ Significant at the $99 \%$ level.

Lastly, we recommend modesty. With Lindblom and Cohen (1979), we believe that everyday knowledge is, if not superior in principle, certainly vastly deeper than management scholars, or other social scientists, can ever attain. We are condemned to mindless waves of fashion in schools of thought, condemned to amnesia, if we do not restrain our ambitions to building on the know-how of the laity. If the field studies we report on have had the insights that we claim, it was not because their authors were smarter or better trained than anyone else. It was because they learned from smart practitioners. And they learned, like all who must learn tacit social knowledge, in apprenticeship roles, in practice (Lave \& Wenger, 1991).

1. These are called Ricardian rents (based on superior resources), or Pareto-Marshall rents (based on superior use of a resource) not entrepreneurial rents (based on superior bets about an uncertain future) (Rumelt, 1987). Does this mean these activities are not entrepreneurial? We think not, for two reasons. Entrepreneurs may bet on resource enhancements that they view as less risky than others do (cf. Cooper, Woo, \& Dunkelberg, 1988), because of their intensive and tacit knowledge of the idiosyncratic means of input completion. If so, the three types of rent are in practice fused. Moreover, proposing that there are different "types" of rent, rather than different causes of high profits, is a misleading reification. Underlying the concept of rent is the assumption that unusual profits require explanation because they do not match the models of neoclassical economics. But neoclassical assumptions themselves are ill-suited for understanding entrepreneurship, or competitive advantage more broadly (Hunt \& Morgan, 1995).

2. This helps to explain the finding in studies of managerial work that the manager's job is fragmented, filled with endless brief interactions and not subject to time planning. Note that we are referring mainly to incremental innovations within the "induced strategic behavior loop" of Burgelman's (1983) model, not the "autonomous strategic behavior loop" associated with internal corporate venturing. We see the former, not just the latter, as entrepreneurial, because it creates (dare we say this?) rent (Stewart, 1989, p. 63).

3. Theories of core competencies (Prahalad \& Hamel, 1990) and firm resource theory (Wernerfelt, 1995) are related, in their focus on competing through superior resources, but they have not focused as much as the other approaches on work flows and work systems.

4. U.S. field researchers, such as Arensberg, Richardson, Sayles, and Whyte, and British (Tavistock) sociotechnical systems researchers, such as Jaques, Rice, and Trist, both conducted field studies of work systems. However, their work was done independently, with little or no cross-fertilization.

5. Organizing according to work flow process, not functions, was not the only lesson to be gleaned in these studies. Three other solutions that they offered, which are also compatible with reengineering, are the use of teams, empowerment of line rather than staff managers, and persistent learning. (See Richardson, 1961, pp. 73, 75; Richardson \& Walker, 1959; Sayles, 1962a, p. 66; Sayles \& Strauss, 1966, chap. 9; Whyte, 1949, chap. 14; 1969, p. 636.)

6. "University professors in many departments ... write volumes of abstract interpretation based on minimal data" (Richardson, 1961, p. 76).

7. "We" in this case is Stewart, collaborating with David Krackhardt.

8. The index terms for the Affective/Personality relation are ANGER, ANXIETY, EMOTION, ENCOURAGE, EXHORT, $S T I R$, and TRUST. The index terms for the Work relation are EV(ery)DAY TASK, EXPEDITE, HOUSEKEEP, MAINT(enance), PROC(ess) DES(ign), PROD(ess) DES(ign), PRODUCTION, QA, SELLING, SETUP, SHIPPING, TOOLING, UNP(restigious) S(U)PP(o)RT, and WORK. The index terms for the Polity relation are AUTHORITY, 
AUTOCRACY, COMMAND, CONFLICT, DELEGATE, NEGOTIATE, PART(icipatio)N, PART(icipatio)N LOW (in the ranks), POL INT (i.e., internal politics), POWER, and RIVALRY. These sets of terms are pared down versions of lists that were created to capture the broadest implications of the four metaphors. These lists were checked for inter-rater reliability (with Kevin Learned), with whom an $80.4 \%$ agreement obtains; $88.4 \%$ post-explanation of some of the index terms' actual uses. The shorter sets were created in order to exclude two types of terms. Some terms in the broader sets were included because of our outsiders' attributions about meaning, but not because this meaning was directly observed. For example, we assume that BENEFITS affects motivation, and hence belongs in the Affective relation. Other terms are problematic because they often refer to discussions of a topic, such as someone else's anger, so that treating them (as in the broader list) as Affective, rather than Cognitive, is questionable. The terms used here were selected as reflecting core meanings of the relations in question, and being used in contexts in which the topic (e.g., Anger) was actually observed being "sent" from one actor (actor i) to another (actor $\mathrm{j}$, in network jargon).

9. CONCOR has limitations, as Wasserman and Faust (1994, p. 380) argued. However, using their preferred approach to correlational hierarchical clustering results in very similar correlations and what Burt (1976) called structurally unique positions (SUPs). Assigning actors to SUPs requires judgment, whereas CONCOR, for better or worse, partitions actors to distinct positions with no judgments by the researcher.

\section{REFERENCES}

Aldrich, H. E. (1992). Methods in our madness? Trends in entrepreneurship research. In D. L. Sexton \& J. D. Kasarda (Eds.), The state of the art of entrepreneurship, pp. 191-209. Boston: PWS-Kent.

Arensberg, C. M., \& Tootell, G. (1957). Plant sociology: Real discoveries and new problems. In M. Komarovsky (Ed.), Common frontiers of the social sciences, pp. 310-337. Glencoe, IL: Free Press.

Borgatti, S. P., Everett, M. G., \& Freeman, L. C. (1992). UCINET IV Version 1.4 Columbia, SC: Analytic Technologies.

Brajkovich, L. F. (1994). Sources of social structure in a start-up organization: Work networks, work activities, and job status. Social Networks, 16, 191-212.

Breiger, R. L., Boorman, S. A., \& Arable, P. (1975). An algorithm for clustering relational data with applications to social network analysis and comparison with multidimensional scaling. Journal of Mathematical Psychology, 12, 328-383.

Burgelman, R. A. (1983). Corporate entrepreneurship and strategic management: Insights from a process study. Management Science, 29, 1349-1364.

Burgelman, R. A. (1984). Designs for corporate entrepreneurship. California Management Review, 26(2), 154166.

Burgelman, R. A., \& Sayles, L. R. (1986). Inside corporate innovation. New York: Free Press.

Bums, T., \& Stalker, G. M. (1966). The management of innovation (2nd ed.). London: Tavistock.

Burt, R. S. (1976). Positions in social networks. Social Forces, 55, 93-122.

Burt, R. S. (1983). Distinguishing relational contents. In R. S. Burt \& M. J. Minor (Eds.), Applied network analysis, pp. 35-74. Beverly Hills, CA: Sage.

Byrne, J. A. (1993). The horizontal corporation. Business Week, December 20, 76-81.

Chapple, E. D., \& Sayles, L. R. (1961). The measure of management: Designing organizations for human effectiveness. New York: Macmillan.

Cooper, A. C., Woo, C. Y., \& Dunkelberg, W. C. (1988). Entrepreneurs' perceived chances for success. Journal of Business Venturing, 3, 97-108.

Covin, J. G., \& Slevin, D. P. (1991). A conceptual model of entrepreneurship as firm behavior. Entrepreneurship Theory and Practice, 16(1), 7-25.

Dalton, M. (1959). Men who manage. New York: Wiley. 
Guest, R. (1962). Discussion [of Sayles, 1962a, and other work]. Human Organization, 21, 83.

Hackman, J. R., \& Suttle, J. L. (1977). Improving life at work. Santa Monica, CA: Goodyear.

Hammer, M., \& Champy, J. (1993). Reengineering the corporation. New York: Harper Business.

Herzberg, F., Mausner, B., \& Snyderman, B. (1959). The motivation to work (2nd ed.). New York: Wiley.

Hunt, S. D., \& Morgan, R. M. (1995). The comparative advantage theory of competition. Journal of Marketing (forthcoming).

Johnson, J. C., \& Miller, M. L. (1986). Behavioral and cognitive data: A note on the multiplexity of network subgroups. Social Networks, 8, 65-77.

Lave, J., \& Wenger, E. (1991). Situated learning: Legitimate peripheral participation. New York: Cambridge University Press.

Leibstein, H. (1968). Entrepreneurship and economic development. American Economic Review, 58, 72-83.

Lindblom, C. E., \& Cohen, D. K. (1979). Usable knowledge. New Haven, CT: Yale University Press.

Morgan, G. (1986). Images of organization. Beverly Hills, CA: Sage.

Morey, N. C., \& Luthans, F. (1987). Anthropology: The forgotten discipline in management thought. In F. Hoy

(Ed.), Best paper proceedings, Academy of Management, pp. 128-132.

Perrow, C. (1979). Complex organizations: A critical essay. Glenview, IL: Scott Foresman.

Pettigrew, A. (1973). The politics of organizational decision making. London: Tavistock.

Pfeffer, J. (1992). Managing with power. Boston: Harvard Business School Press.

Porter, L. W., \& McGibbin, L. E. (1988). Management education and development. New York: McGraw-Hill.

Prahalad, C. K., \& Hamel, G. (1990). The core competence of the corporation. Harvard Business Review, MayJune, 79-91.

Rice, A. K. (1955). Studies of an Indian mill. Human Relations, 8, 199-249, 297-329.

Richardson, F. L. W., Jr. (1961). Talk, work, and action: Human reactions to organizational change. Ithaca, NY: The Society for Applied Anthropology.

Richardson, F. L. W., Jr., \& Walker, C. R. (1949). Work flow and human relations. Harvard Business Review, Jan., 107-122.

Richardson, F. L. W., Jr., \& Zimmerman, S. (1965). Comprehending the process of organizational improvement. Management of Personnel Quarterly, 4(1), 3-15.

Rumelt, R. (1987). Theory, strategy, and entrepreneurship. In D. J. Teece (Ed.), The competitive challenge, pp. 137-158. Cambridge, MA: Ballinger.

Sayles, L. R. (1962a). The change process in organizations: An applied anthropology analysis. Human Organization, 21, 62-67.

Sayles, L. R. (1962b). Discussion [of Sayles, 1962, and other work]. Human Organization, 21, 82-85.

Sayles, L. R. (1993). The working leader: The triumph of high performance over conventional management principles. New York: Free Press.

Sayles, L. R., \& Strauss, G. (1966). Human behavior in organizations. Englewood Cliffs, NJ: Prentice Hall.

Schonberger, R. J. (1986). World class manufacturing. New York: Free Press.

Schumpeter, J. A. (1943). Capitalism, socialism and democracy. London: George Allen \& Unwin.

Seidel, J. V., Kjolseth, R., \& Seymour, E. (1988). The Ethnograph, Version 3.0. Corvallis, OR (now Amherst, MA): Qualis Research Associates.

Slichter, S. (1941). Union policies and industrial management. Washington, DC: Brookings Institution.

Stevenson, H. H., \& Jarillo, J. C. (1990). A paradigm of entrepreneurship: Entrepreneurial management. Strategic Management Journal, 11 (Summer), 17-27.

Stewart, A. (1989). Team entrepreneurship. Newbury Park, CA: Sage.

Stewart, A. (1994). From data to theory on team entrepreneurship: What difference does a computer make? Paper presented at Symposium on Challenges in Conducting Field Research on Firm Level Entrepreneurship, National Academy of Management Meetings, August 17, 1994, Dallas, TX. 
Stewart, A. (1995). Journal ranking in Nacirema ritual: The case of I. C. MacMillan's publishing "forums." Advances in Strategic Management, 12(A), 3-37.

Stewart, A., \& Krackhardt, D. (1995). Content makes all the difference: How ethnographers can contribute to and improve social network analysis. Unpublished manuscript.

Trist, E. L., Higgin, G. W., \& Murray, H. (1963). Organizational choice. London: Tavistock.

Venkataraman, S., MacMillan, I. C., \& McGrath, R. G. (1992). Progress in research on corporate venturing. In D. L. Sexton \& J. D. Kasarda (Eds.), The state of the art of entrepreneurship, pp. 487-519. Boston: PWS-Kent.

Wasserman, S., \& Faust, K. (1994). Social network analysis: Methods and applications. New York: Cambridge University Press.

Wernerfelt, B. (1995). The resource-based view of the firm: Ten years after. Strategic Management Journal, 16, 171-174.

Whyte, W. F. (1949). Human relations in the restaurant industry. New York: McGraw-Hill.

Whyte, W. F. (1969). Organizational behavior. Homewood, IL: Irwin-Dorsey.

Womack, J.P., Jones, D. T., \& Roos, D. (1990). The machine that changed the world. New York: Rawson Associates.

Zahra, S. A. (1993). A conceptual model of entrepreneurship as firm behavior: A critique and extension. Entrepreneurship Theory \& Practice, 17(4), 5-21. 